\title{
Long-term changes in the hydrological regime of high mountain Lake Morskie Oko (Tatra Mountains, Central Europe)
}

\author{
Mariusz Ptak ${ }^{*}$, Dariusz Wrzesiński, Adam Choiński \\ Institute of Physical Geography and Environmental Planning, Adam Mickiewicz University, Dzięgielowa 27, 61680 Poznań, Poland. \\ *C Corresponding author. E-mails: marp114@wp.pl, darwrze@amu.edu.pl, choinski@amu.edu.pl
}

\begin{abstract}
The paper discusses changes in the hydrological regime of high mountain Lake Morskie Oko located in the Tatra Mountains, in the Tatra Mountains National Park, a UNESCO biosphere reserve (MaB). According to the research conducted in the years 1971-2015, its water stages decreased by $3.5 \mathrm{~cm} \cdot \mathrm{dec}^{-1}$, mean annual water temperature increased by $0.3^{\circ} \mathrm{C} \cdot \mathrm{dec}^{-1}$ and the duration of ice phenomena and ice cover was reduced by $10 \mathrm{day} \cdot \mathrm{dec}^{-1}$. No considerable changes in maximum values of ice cover thickness were recorded. Such tendencies are primarily caused by long-term changes in climatic conditions - air temperature and atmospheric precipitation. The hydrological regime of the lake was also determined by changes in land use in the lake's catchment and its location in high mountains.
\end{abstract}

Keywords: Water temperature; Ice phenology; Water level; Climate change; Tatra Mountains.

\section{INTRODUCTION}

The observed environmental changes are particularly reflected in the course of various processes and phenomena occurring in lakes. They are generally associated with a change in the hydrological regime, according to Apsite et al. (2014) encompassing characteristic water stages, temperature and ice phenomena. The features of the hydrological regime result from natural and anthropogenic processes. As emphasised by Jańczak and Choiński (1988), it is often very difficult or even impossible to identify its main constituent. The situation seems to be more transparent in the case of high mountain lakes. Due to their location and inaccessibility, they are not exposed to large-scale anthropopressure. Assuming that such lakes are not exposed to harmful influences including wastewater and heated water discharge, melioration works, etc., the primary causes of changes occurring in these ecosystems should be particularly associated with natural conditions. It should be emphasised, however, that even such lakes are indirectly affected by human activity through air pollution (Moiseenko et al., 1997; Van Drooge et al., 2011) or grazing of animals (Tiberti et al., 2014). Due to their quasi-natural state, mountain lakes are frequently used as indicators of climatic changes (Hamerlík and Bitušík, 2009). Limnological literature includes a number of publications concerning high mountain lakes, showing the specificity of their functioning (in comparison to lowland lakes of the same latitudes) regarding various aspects, including their biotic (Dočkalová et. al., 2015; Hamerlik et al., 2016; Kawecka and Galas, 2003; Lenarczyk and Tsarenko, 2013; Procházková et al., 2012) and abiotic environment (Gąsiorowski and Sienkiewicz, 2010; Ivanković et. al. 2011; Kabała and Bojko, 2014; Rzychoń and Worsztynowicz, 2008). Lakes located in protected areas should be recognised as particularly valuable. An example of such a lake is Lake Morskie Oko, analysed in this paper, located in the Tatra Mountains in the Tatra Mountains National Park, constituting a UNESCO World Biosphere Reserve (MaB).

The objective of the paper is to analyse changes in the hydrological regime of Lake Morskie Oko and to evaluate factors controlling such changes. In particular, the aim is to identify changes in lake water levels, water temperature dynamics and ice cover changes in the period 1971-2015.

\section{Study object}

High mountain Lake Morskie Oko (1395 m a.s.1.) is located in Central Europe in the Tatra Mountains, the highest mountain range of the Carpathians (Fig. 1). The Tatra Mountains are located in the Central part of Western Carpathians, developing the physical-geographical macroregion of Łańcuch Tatrzański. The area of the Tatra Mountains is approximately $790 \mathrm{~km}^{2}$. Approximately $22 \%$ of of the area is located in the territory of Poland, and the remaining part in Slovakia. The Polish Tatra Mountains feature approximately 40 lakes with a total area of 160 ha and total volume of lake basins of 40 million $\mathrm{m}^{3}$ (Ziemońska, 1974).

Morskie Oko is a lake of moraine origin. It fills a rock basin formed by glaciers, closed to the north by a bar underlying the terminal moraine rampart. The lake itself has an area of 33.39 ha. It has a maximum depth of $51.8 \mathrm{~m}$, mean depth of $29.7 \mathrm{~m}$ and water volume of $9904.3 \times 10^{3} \mathrm{~m}^{3}$. The maximum water transparency determined by means of a Secchi disc is $17.5 \mathrm{~m}$. The catchment of Lake Morskie Oko has an area of $5.9 \mathrm{~km}^{2}$. It is dominated by rock outcrops and debris. The vegetation cover includes mountain pine and grassy vegetation. The forest assemblages are of an island character, and are located in the direct vicinity of the lake. The network of streams is mainly of a periodical and episodic character (Wit-Jóźwik, 1974).

\section{DATA AND METHODS}

The paper is based on systematic observations conducted by the Institute of Meteorology and Water Management (IMGW) in the period 1971-2015, including data on air temperature (daily means), precipitation (daily totals), water stages (in situ readings), surface water temperature (point measurements at a depth of $0.4 \mathrm{~m}$ under the water surface) and ice cover (dates of the commencement and cessation of ice phenomena, dates of the commencement and cessation of ice cover, persistence of ice phenomena and ice cover, thickness of the ice cover). The detection and estimation of trends in the time series involved the application of Excel template MAKESENS (Mann- Kendall test) developed by researchers from the Finnish Meteorological Institute (Salmi et al., 2002). 


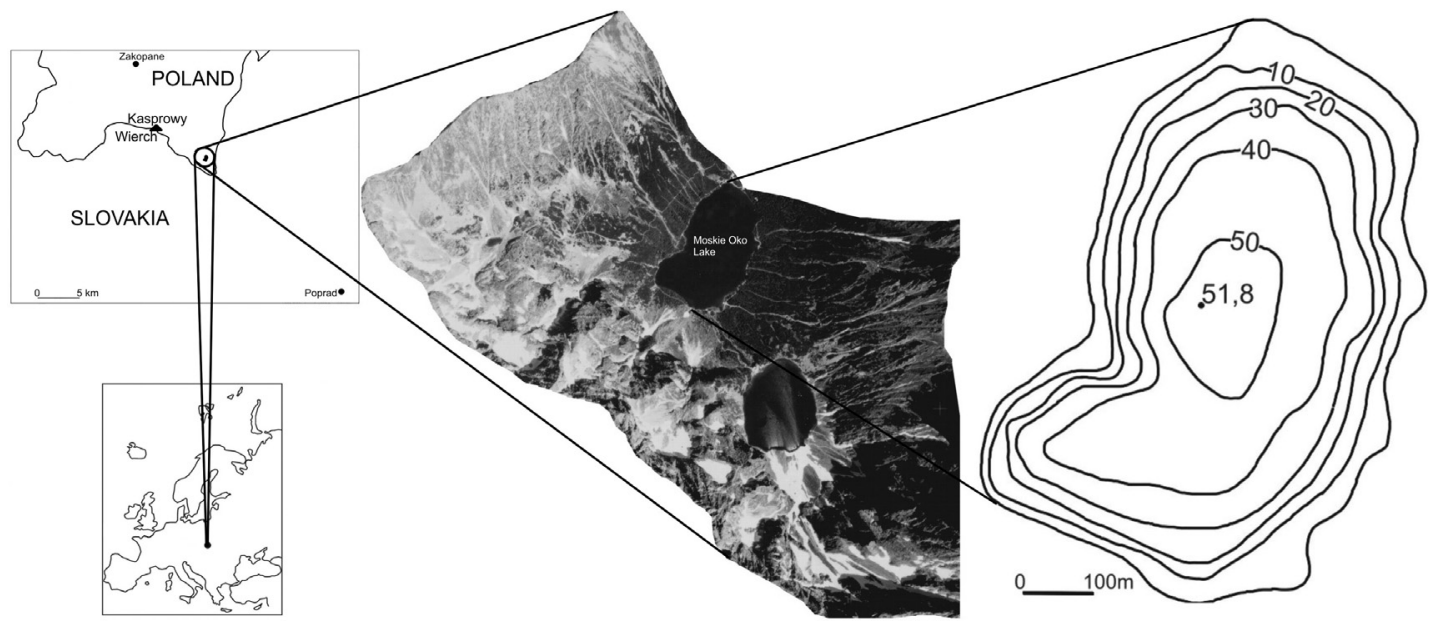

Fig. 1. Location of the study object - Lake Morskie Oko and its catchment.

The Mann-Kendall test is applicable in cases when the data values $x_{i}$ of a time series can be assumed to obey the model:

$x_{i}=f(t)+\varepsilon_{i}$,

where $f(t)$ is a continuous monotonic increasing or decreasing function of time and the residuals $\varepsilon_{i}$ can be assumed to be from the same distribution as zero mean. It is therefore assumed that the variance of the distribution is constant in time. The MannKendall test statistic $S$ is calculated according to the formula:

$S=\sum_{k=1}^{n-1} \sum_{j=k+1}^{n} \operatorname{sgn}\left(x_{j}-x_{k}\right)$

where $x_{j}$ and $x_{k}$ are annual values in years $j$ and $k, j>k$, respectively, and:

$$
\operatorname{sgn}\left(x_{j}-x_{k}\right)=\left\{\begin{array}{c}
1 \text { if } x_{j}-x_{k}>0 \\
0 \text { if } x_{j}-x_{k}=0 \\
-1 \text { if } x_{j}-x_{k}<0
\end{array}\right.
$$

An upward (increasing) or downward (decreasing) trend by a positive or negative value of $Z$. First the variance of $S$ is computed by the following equation (4) which takes into account that ties may be present:

$$
V A R(S)=\frac{1}{18}\left[n(n-1)(2 n+5)-\sum_{p=1}^{q} t_{p}\left(t_{p}-1\right)\left(2 t_{p}+5\right)\right]
$$

where $q$ is the number of tied groups and $t p$ is the number of data values in the pth group. The values of $S$ and $V A R(S)$ are used to compute the test statistic $Z$ as follows:

$$
Z= \begin{cases}\frac{S-1}{\sqrt{\operatorname{VAR}(S)}} & \text { if } S>0 \\ 0 & \text { if } S=0 \\ \frac{S+1}{\sqrt{\operatorname{VAR}(S)}} & \text { if } S<0\end{cases}
$$

Then, the null hypothesis of no trend $H_{0}$, is tested in order to accept or reject it. The $x_{i}$ observations are randomly ordered chronologically, contrary to the alternative hypothesis $H_{1}$ with an increasing or decreasing monotonic trend. The statistic test $Z$ (normal approximation) is computed because all-time series are longer than ten. The statistic $Z$ has a normal distribution. The absolute value of $Z$ can be compared to the standard normal cumulative distribution to identify a monotone trend or its lack at the specified level of significance.

Calculations of coefficients of correlation concerned both synchronic and asynchronic series. The statistical assessment of significance of correlation coefficients was performed by means of t-statistic. Results of the correlation analysis were presented graphically in the form of matrices of 159 coefficients of correlation.

\section{RESULTS}

Tendencies of changes in parameters of the hydrological regime of Lake Morskie Oko and meteorological elements

According to the research, monthly, seasonal, as well as annual water stages in the lake show significant decreasing tendencies. Considerable changes in water stages particularly occurred following the period of ice cover persistence from June to October, at a level of $p<0.001$ (Table 1, Fig. 2). Evidently increasing trends occur in the case of water temperature in the lake in the warm part of the year. Mean monthly water temperatures from May to September show a marked increase at a significance level of $\mathrm{p}<0.001$. Within a multiannual period, an increasing tendency in water temperatures is also observed in October, although at a less statistically significant level of $\mathrm{p}<0.05$ (Table 1, Fig. 3).

Statistically significant trends have also been observed with respect to the parameters of ice phenomena (referring to any form of ice in water recorded during the observations, i.e. shore ice, floating ice, ice cover, etc.). Both the commencement of ice phenomena and the appearance of compact ice cover on the lake occur increasingly later. The term of termination of those parameters of ice phenomena is increasingly earlier (Fig. 4, Table 2). The terms of commencement of ice phenomena and ice cover as well as those of their termination show very statistically significant trends $(\mathrm{p}<0.001)$. As a consequence, the duration of ice phenomena and persistence of ice cover is increasingly shorter, and the observed changes are statistically significant at a level of $\mathrm{p}<0.001$ (Table 2, Fig. 5). Among the analysed characteristics of ice phenomena, only maximum thickness of ice cover shows no statistically significant change (Fig. 6). 
Table 1. Results of the Z Mann-Kendall test of monthly and annual water stages in the years 1971-2015.

\begin{tabular}{|c|c|c|c|c|c|c|c|c|c|c|c|c|c|}
\hline & Nov & Dec & Jan & Feb & Mar & Apr & May & Jun & Jul & Aug & Sep & Oct & Year \\
\hline \multicolumn{14}{|c|}{ Morskie Oko Lake } \\
\hline Water stages & -2.43 & -2.91 & -2.10 & -1.65 & -0.70 & -1.58 & -2.27 & -3.97 & -3.70 & -4.12 & -4.20 & -3.64 & -3.07 \\
\hline Water temperature & 1.55 & -0.24 & -1.59 & -1.66 & -1.35 & 0.45 & $\underline{4.31}$ & $\overline{4.59}$ & 4.71 & $\overline{4.34}$ & $\underline{3.40}$ & 2.91 & $\underline{5.10}$ \\
\hline \multicolumn{14}{|c|}{ Meteorological conditions } \\
\hline Precipitation & 0.45 & -2.33 & 0.48 & 1.16 & 1.06 & $\begin{array}{l}-1.39 \\
\end{array}$ & 0.97 & -1.18 & 0.16 & -1.28 & -0.20 & 1.27 & 0.0 \\
\hline Temperature & 2.82 & 0.35 & -0.12 & -0.49 & -0.50 & 3.74 & 1.65 & $\underline{3.43}$ & $\underline{3.63}$ & $\underline{3.43}$ & 0.65 & 1.18 & $\underline{4.47}$ \\
\hline
\end{tabular}

Statistical significance: italic $-p<0.05$, bold $-\mathbf{p}<\mathbf{0 . 0 1}$, bold $-\mathbf{p}<\mathbf{0 . 0 0 1}$

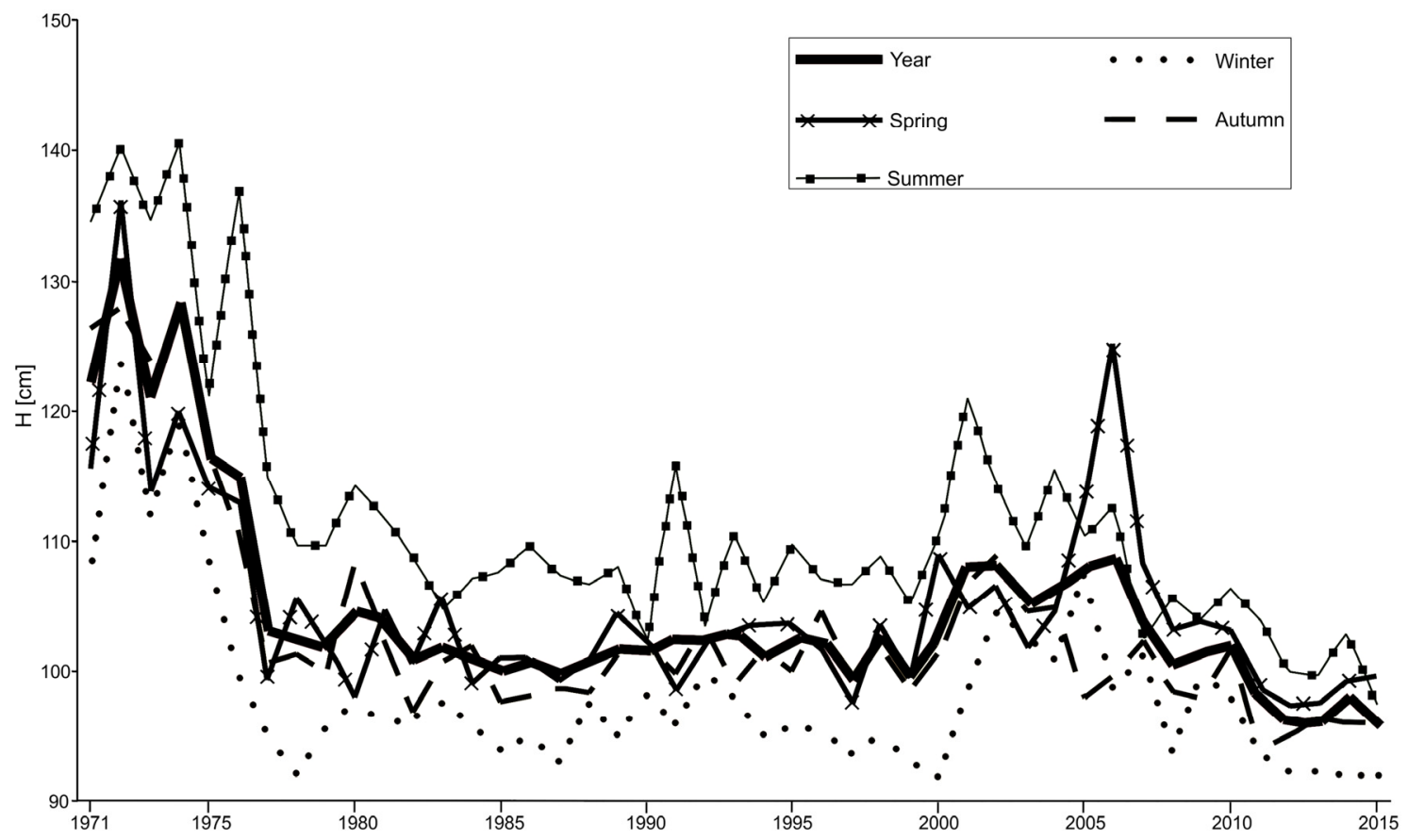

Fig. 2. Changes in water stages (H) in Lake Morskie Oko in the years 1971-2015.

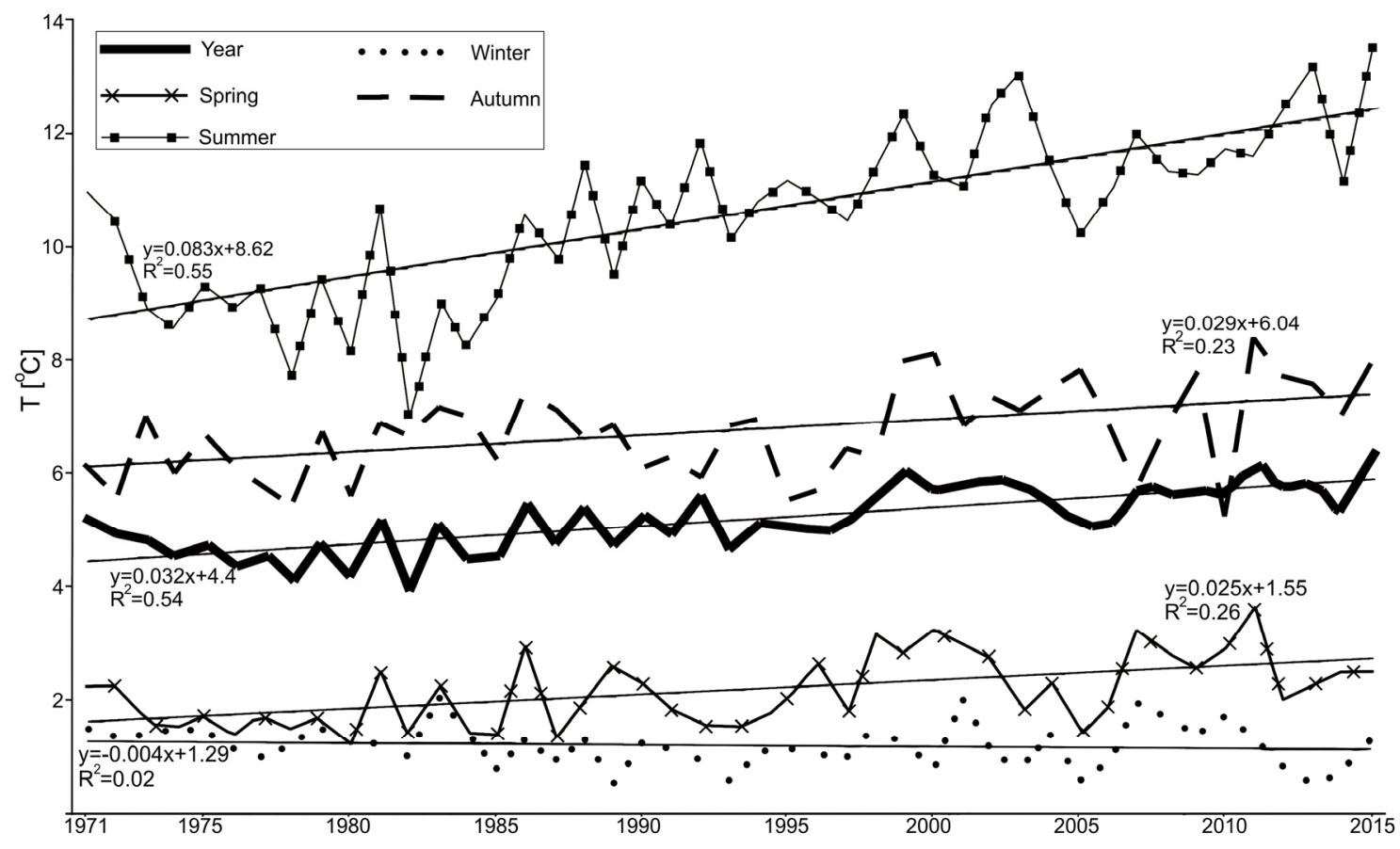

Fig. 3. Changes in water temperature (T) in Lake Morskie Oko in the years 1971-2015. 
Table 2. Results of the Z Mann-Kendall test of parameters of ice phenomena of Lake Morskie Oko in the years 1971-2015.

\begin{tabular}{ccccccc}
\hline $\begin{array}{c}\text { Start of ice } \\
\text { phenomena }\end{array}$ & $\begin{array}{c}\text { Start of ice } \\
\text { cover }\end{array}$ & $\begin{array}{c}\text { End of ice } \\
\text { phenomena }\end{array}$ & $\begin{array}{c}\text { End of ice } \\
\text { cover }\end{array}$ & $\begin{array}{c}\text { Max. thickness } \\
\text { of ice cover }\end{array}$ & $\begin{array}{c}\text { Duration of ice } \\
\text { phenomena }\end{array}$ & $\begin{array}{c}\text { Duration of ice } \\
\text { cover }\end{array}$ \\
\hline$\underline{\mathbf{3 . 4 1}}$ & $\mathbf{2 . 9 9}$ & $\underline{\mathbf{3 . 7 0}}$ & $\underline{\mathbf{- 4 . 3 9}}$ & -0.75 & $\underline{\mathbf{5 . 0 2}}$ & $\mathbf{- 4 . 1 6}$ \\
\hline
\end{tabular}

Statistical significance: italic $-p<0.05$, bold $-\mathbf{p}<\mathbf{0 . 0 1}$, $\underline{\text { bold }-\mathbf{p}<\mathbf{0 . 0 0 1}}$

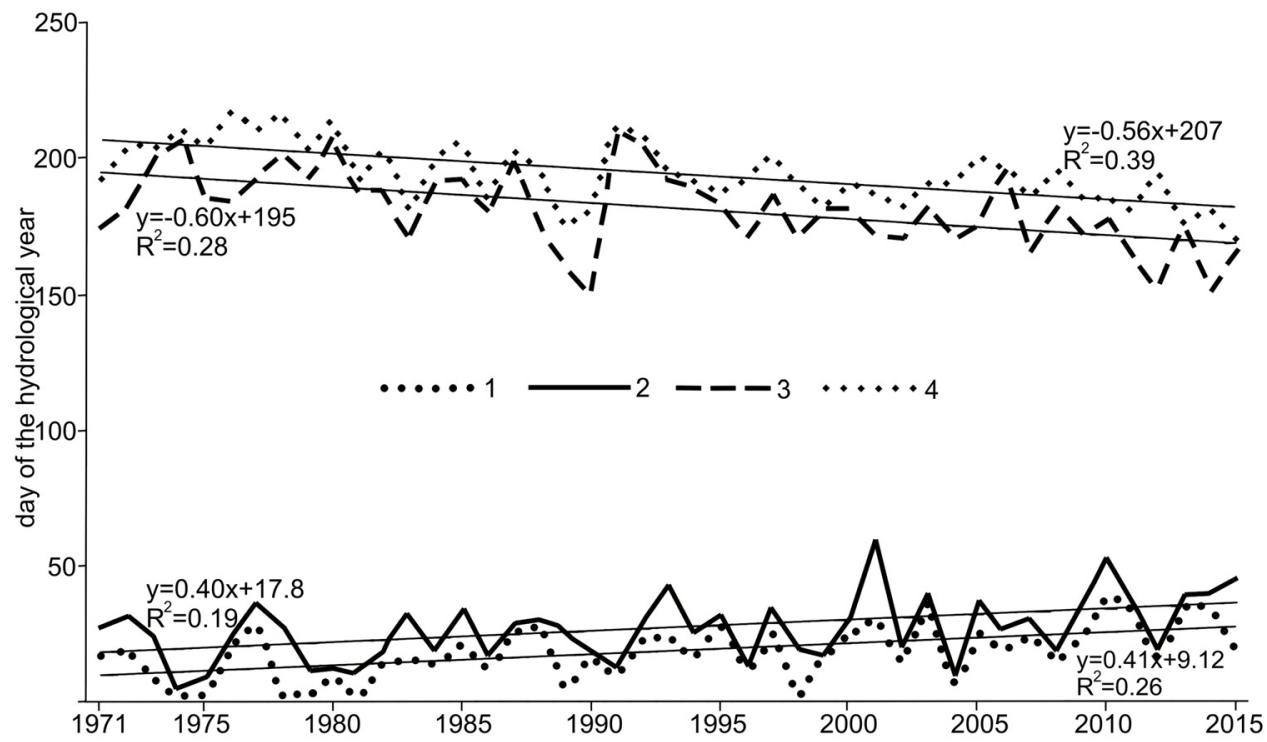

Fig.4. Changes in the term of the start and end date of ice phenomena and ice cover on Lake Morskie Oko in the years 1971-2015. 1- start of ice phenomena, 2- start of ice cover, 3- end of ice cover, 4- end of ice phenomena.

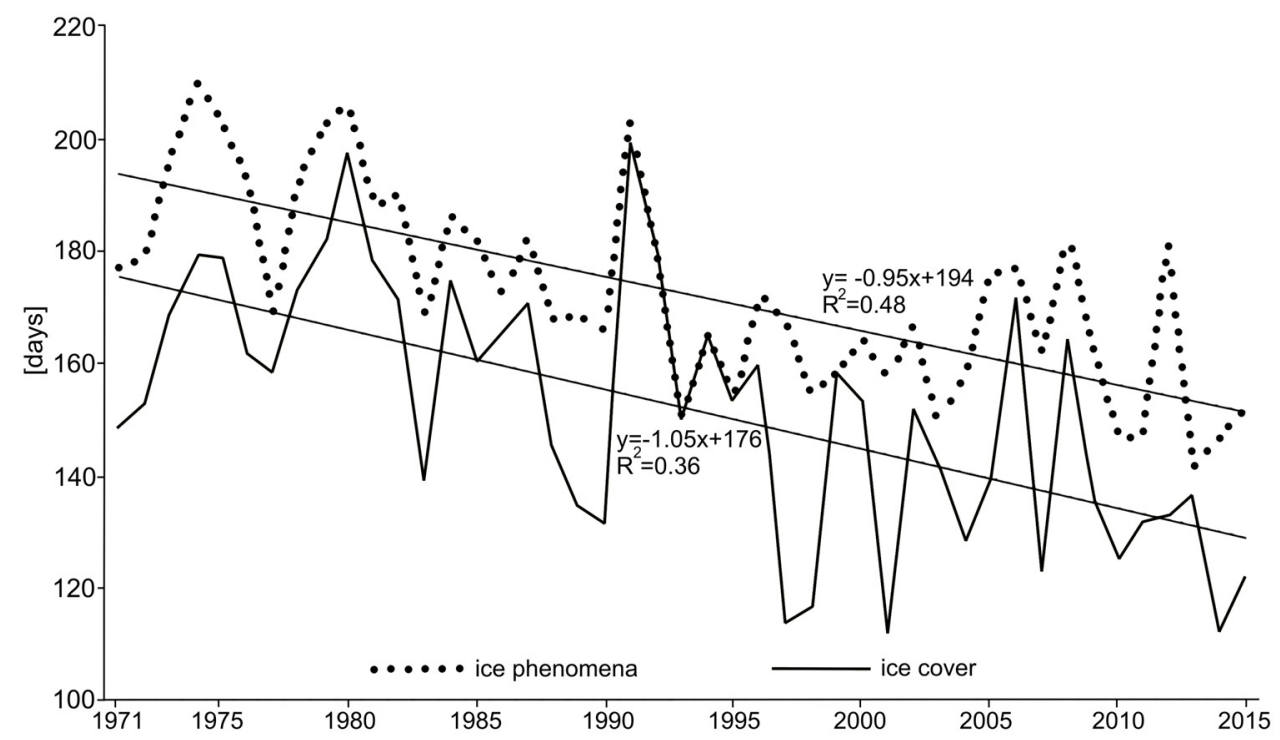

Fig.5. Changes in the duration of ice phenomena and ice cover (days) on Lake Morskie Oko in the years 1971-2015.

Changes in air temperature recorded at the Kasprowy Wierch station reveal a statistically significant increase from April to August (average $0.54^{\circ} \mathrm{C} \cdot \mathrm{dec}^{-1}$ ) and in November (average $\left.0.60^{\circ} \mathrm{C} \cdot \mathrm{dec}^{-1}\right)$. The most significant increase concerns mean monthly air temperatures in April and June $(\mathrm{p}<0.001)$. Moreover, mean air temperature shows a distinct growth $(p<0.001)-$ Table 1. In the multiannual period, no statistically significant changes in total monthly or annual atmospheric precipitation have been recorded at the Morskie Oko station with the exception of the precipitation total in December which shows a statistically significant decrease $(\mathrm{p}<0.05)$.
Meteorological conditions of changes in parameters of the hydrological regime of Lake Morskie Oko

The effect of air temperature on the thermal dynamics of the lake's water is obvious and unquestionable. After the period of occurrence of ice phenomena, strong positive correlations are observed between air temperature and water temperature in the lake from April to September. With the exception of April, for the remaining months, the calculated coefficients of correlation are high, and very statistically significant ( $<<0.001)$ (Fig. 7). 


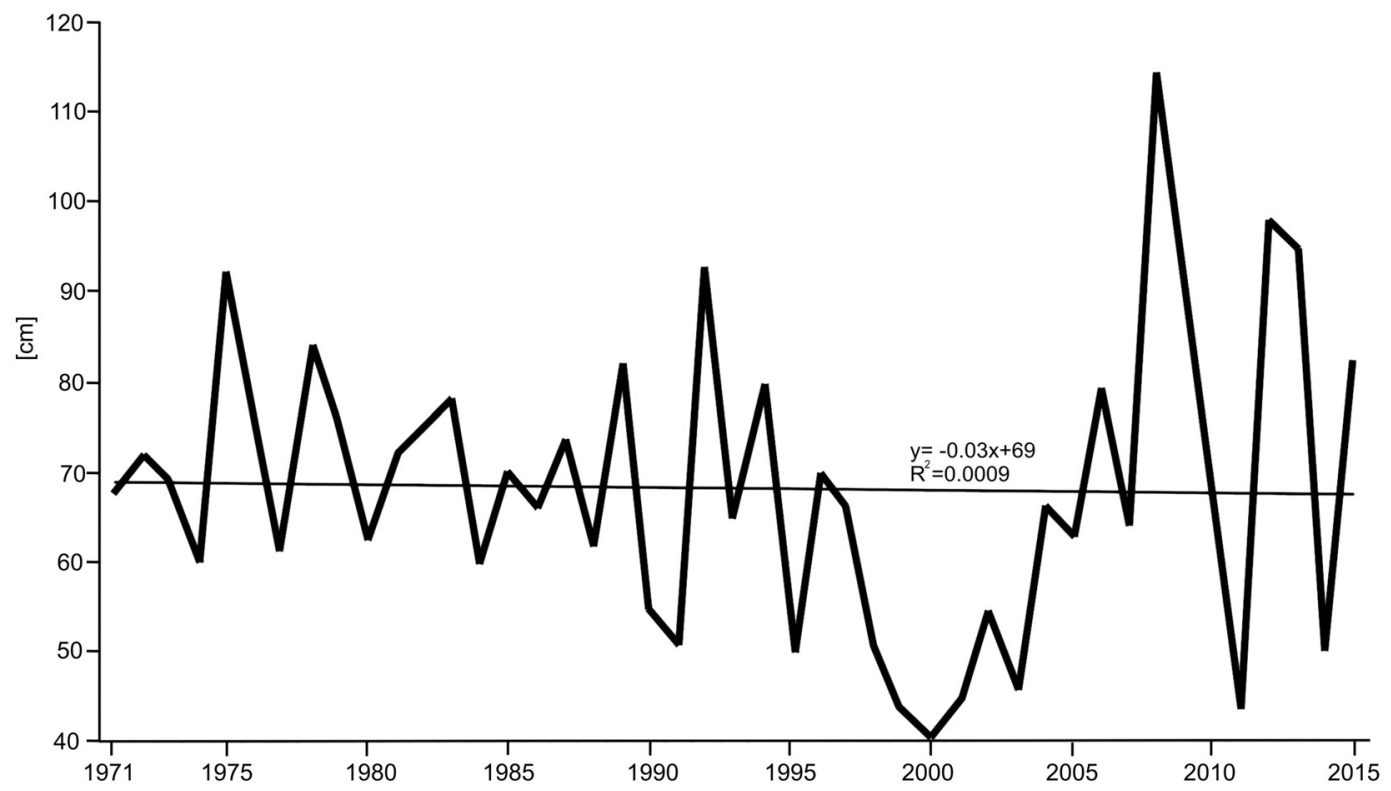

Fig. 6. Changes in the maximum thickness (cm) of the ice cover in the years 1971-2015.
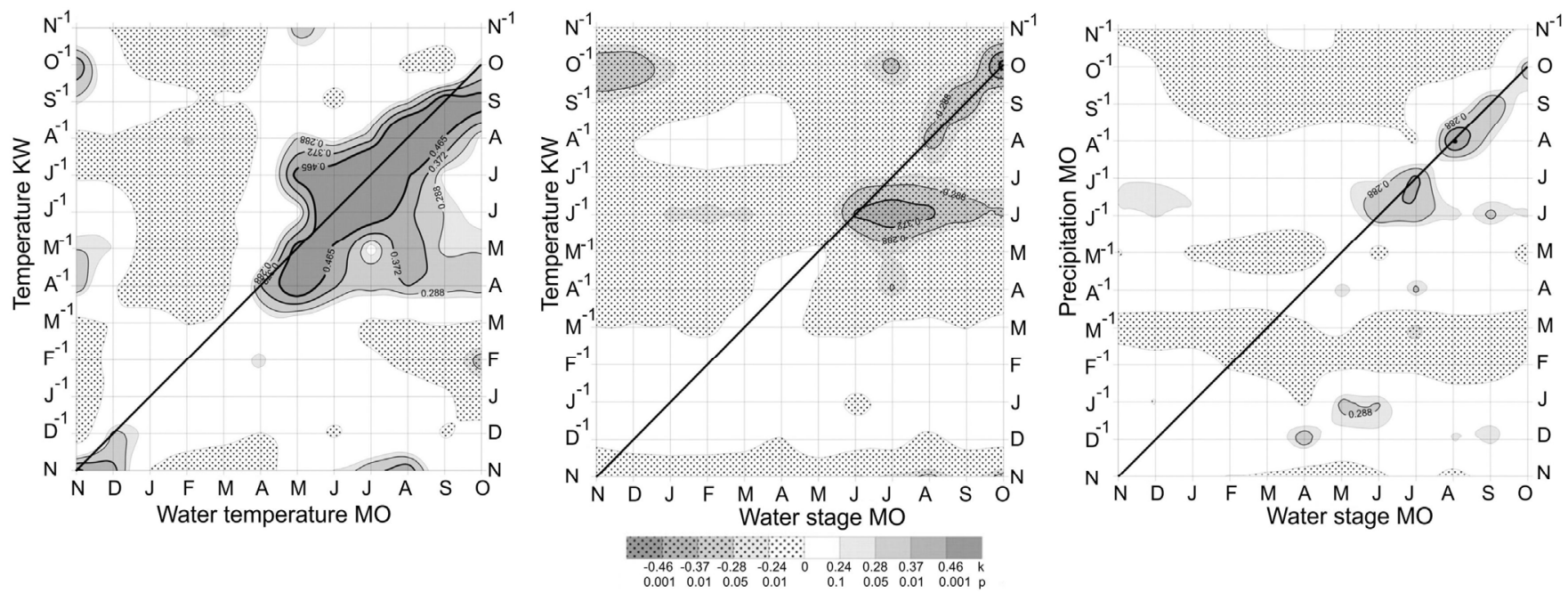

Fig. 7. Matrix of coefficients of correlation of monthly: a) air temperatures (Kasprowy Wierch meteorological station - KW) and water temperatures in Morskie Oko - MO, b) air temperatures (KW) and water stages in Morskie Oko - MO, c) atmospheric precipitation (MO) and water stages in Morskie Oko - MO (in months $\mathrm{D}^{-1}, \mathrm{~J}^{-1} \ldots \mathrm{N}^{-1}$, air temperature and atmospheric precipitation values from the preceding year).

The research showed that in the summer months, air temperature also has an effect on water stages in the lake. This is evidenced by negative coefficients of correlation between air temperature in June and water stages from June to August $(\mathrm{p}<0.01)$, as well as between air temperature in September and October and synchronic water stages in the lake (Fig. 7). Atmospheric precipitation is also an important meteorological element affecting water stages in the lake. As suggested by the matrix of coefficients of correlation with water stages in the lake, in the summer half-year, monthly precipitation totals (from June to October) show a positive correlation with water stages, and the coefficients of correlation are statistically significant. In the winter half-year, only precipitation in January is positively correlated with water stages in the lake in May and June, i.e. in the months following the decline of the ice cover (Fig. 7).

\section{DISCUSSION}

The conducted analysis suggests that elements of the hydrological regime of Morskie Oko have been subject to considerable changes over the last several decades. The majority of the parameters indicated a decreasing tendency: a decrease in water stages was recorded, as well as a delayed term of appearance of ice phenomena and ice cover and earlier term of their termination. This consequently determined the shorter duration of both of these characteristics. Only water temperature showed an increasing tendency.

In reference to particular elements of the hydrological regime of Morskie Oko; in the case of water stages, evident changes are observed in the second half of the 1970's, when a decrease of approximately $15 \mathrm{~cm}$ occurred (in comparison to annual means). The entire set of information concerning water 
stages in Morskie Oko (systematic measurements began in 1963, and the paper analysed the period from 1971 - in accordance with the period of observations conducted for air temperature and precipitation) shows that the water level in the analysed lake was higher in the 1960's and remained so until the mid 1970's. This was caused by changes in atmospheric precipitation.

The period was distinguished by higher than average precipitation in southern Poland. This is associated with the high activity of cyclonal types of atmospheric circulation as observed by Niedźwiedź and Twardosz (2004). Moreover, Pociask-Karteczka et al. (2014) point out that the increase in water stages in the lake took place in a period that coincided with land cover changes in the catchment. Before covering the area with legal protection in 1955, it was intensively exploited by shepherds. The slopes and moraines were stripped of vegetation, dissected with roads and paths, and screes were not overgrown by dwarf pine. This led to a rapid response of water stages to precipitation and surface runoff. After the establishment of the national park, the catchment area was penetrated by vegetation once again. According to Bukowski (2009), in 1955, the area of the catchment occupied by dwarf pine amounted to 2,417 ha, in 1977 to 7,245 ha, and in 2004 to 15,010 ha. Moreover, the surface area of grasslands and tree stands, both loose and compact, increased. Changes in land cover and land use in the lake's catchment contributed to an increase in evaporation and interception, and consequently to limiting surface runoff and decreasing the water level in the lake in the mid 1970's. The above situation is also determined by climatic factors. Water level fluctuations are associated with global and local climatic changes, responding to changes in evaporation and precipitation (Cengiz, 2011). On the scale of the entire year, no significant correlations were determined between air temperature and water stages, although such correlations occurred in the summer half-year. After the termination of ice phenomena, a situation was recorded in which changes in water stages were determined by air temperature in $20 \%$. The correlation was statistically significant at a level of 0.01 . It is associated with an increase in losses related to evaporation.

Changes in the remaining elements of the hydrological regime of Morskie Oko are in accordance with the majority of studies on lakes in various parts of the world, both in reference to thermal conditions (Adrian et al., 2009; Coats et al., 2006; Hampton et al., 2008) and the course of ice phenomena (Benson et al., 2012; Futter, 2003; Korhonen, 2006; Magee et al., 2016). The scale of transformations depends on the location and local conditions of particular lakes. As emphasised by Thompson et al. (2005), mountain lakes are particularly sensitive to climatic changes. Modelling an increase in water temperature in the summer season for Lake Moaralmsee in the Alps, the author determined that it could increase by up to as much as $12^{\circ} \mathrm{C}$ over the next century. In the case of Lake Morskie Oko, an increase in water temperature by $3.3^{\circ} \mathrm{C}$ occurred in the summer season of the analysed multiannual. Over the entire period discussed in the paper (1971-2015), the total increase in water temperature amounted to $1.2^{\circ} \mathrm{C}$. This increase is approximate to values obtained for lakes located in the lowland area of Poland. For twelve cases of the type, an increase in water temperature ranges from $0.25^{\circ} \mathrm{C} \cdot \mathrm{dec}^{-1}$ to $0.55^{\circ} \mathrm{C} \cdot \mathrm{dec}^{-1}$ (Wrzesiński et. al., 2015).

The recorded evident increase in water temperature will have serious consequences for the functioning of lakes. Water temperature is considered to be a basic parameter (Strong and Maberly, 2011) affecting the scale and rate of many processes occurring in lakes. Changes in the thermal regime are particu- larly important in lakes where the ice cover develops (among others in mountain lakes). With the appearance of ice cover, the effect of external conditions on the water mass is eliminated; wind mixing declines, and energy exchange and light penetration decreases (Choiński et al., 2015a). An increase in temperature contributes to changes in the ice regime (Pawłowski, 2015). In reference to the Tatra Mountains, this suggests high sensitivity of the entire cryosphere to changes in climatic factors (Gądek, 2014).

The majority of the analysed parameters of ice phenomena show decreasing tendencies. The dates of commencement of ice phenomena in water, as well as ice cover, were subject to a considerable delay - by $4 \mathrm{day} \cdot \mathrm{dec}^{-1}$ on the average. Such a situation should be associated with higher water temperature, and therefore growing heat resources accumulated in the water mass of Morskie Oko, a fact which is confirmed by the research of Choiński et al. (2015b). As a consequence, the release of heat to the surroundings occurs over a prolonged period, extending the time for conditions that favour the initiation of development of ice. According to Šporka et al. (2006), the decline of ice in water is to a greater extent determined by external (climatic) processes than those occurring under the ice. The scale of ice decline is even faster (in comparison to the shift of the term of its development), and amounts to approximately 6 day $\cdot \mathrm{dec}^{-1}$. As a result of a delay in the development of ice, and its earlier decline, a considerable reduction in the duration of ice phenomena and ice cover was recorded in the analysed period. It was shorter by 9 and $10 \mathrm{day} \cdot \mathrm{dec}^{-1}$, respectively. Similarly to the course of water temperatures, values of particular characteristics of ice phenomena are approximate to those in lowland lakes in Poland (Marszelewski and Skowron, 2006).

Changes in the maximum thickness of ice cover in Morskie Oko in the analysed period show no statistically significant tendency. The situation is similar with respect to earlier research on this parameter of Morskie Oko (Pociask-Karteczka and Choiński, 2012).

The maximum ice thickness remains at variance with the other characteristics of ice phenomena. A statistically significant reduction in the persistence of the ice cover, and a consequent decrease in the theoretical period in which ice thickness increases, caused no evident changes in the thickness of ice cover. Such a situation is associated with the ablation of the snow cover persisting on the ice, and its repeated freezing. This leads to the growth of ice cover and its double-layered character (so-called black ice, developing from the bottom of the existing ice cover, and white ice - developing on the surface of the ice cover). The scale and rate of melting of snow persisting on ice cover depends on the radiation conditions. In the case of Lake Morskie Oko, it is determined by the orographic parameters of the lake's surroundings (Choiński et al., 2013). For other lakes in the Tatra Mountains, the considerable effect of orographic conditions on ice phenomena is also evident. This is confirmed by research conducted by Gregor and Pacl (2005) or Novikmec et al. (2013) in Slovakia.

The effect of the exposure of mountain lakes to the course of ice phenomena has also been analysed in other mountain ranges. Ohlendorf et al. (2000) describe the impact of topography on ice conditions in Lake Hagelseewli in the Swiss Alps. According to the authors, high scarps on the southern side of the lake reduce radiation on its surface from $15 \%$ to $90 \%$, consequently contributing to long persistence of the ice cover.

The maintenance of the observed trends of changes in particular elements of the hydrological regime will contribute to the transformation of the current parameters of Morskie Oko. An increase in air temperature, and consequently water temper- 
ature will be of particular importance. Such a process has an effect on water mixing in the lake, or its thermal stability (Livingstone, 2003). Based on research on Lake Zurich, Rempfer et al. (2010) determined that climate warming will probably hinder the total mixing of deep lakes even in conditions of strong winds. The strength of the effect of winds in the case of Morskie Oko is weakened by its surroundings that consist of the highest peaks of the Tatra Mountains. In reference to stratification, based on the example of Lake Mondsee (max. depth $68 \mathrm{~m}$ ) in Austria, Dokulil et al. (2010) observed that the average duration of thermal stratification is currently longer by 27 days.

Changes in the physical parameters of lakes will have a decided impact on their hydrobiological conditions. Jeppesen et al. (2010) evidenced that climate warming will contribute to changes in the structure of fish, feeding manners, etc. Based on the analysis of the ichthyofauna of 24 European lakes, Jeppesen et al. (2012) anticipate a considerable decrease in the population of stream trout (Salmo trutta), a coldwater fish. It is the only naturally occurring species in Morskie Oko. Hesse et al. (2014) point to the need for more detailed research on stream trout in the discussed lake in the future.

\section{CONCLUSIONS}

Over recent decades, Lake Morskie Oko has been distinguished by a considerable transformation in elements of its hydrological regime. Such changes are generally associated with climatic as well as local factors. Variability of precipitation and an increase in air temperature were reflected in the course of water level fluctuations, water temperature, and ice phenomena. Local factors also contributed to the observed climatic changes. In the analysed case, these involved both changes in land use in the catchment, and orographic conditions. The former is related to the successive development of the vegetation cover at the time of the establishment of the national park. Through an increase in interception and evapotranspiration, this contributed to the observed long-term water level fluctuations. Orographic conditions are associated with shading of the lake which as described in earlier papers, is of importance for the course of ice phenomena. Due to its high mountain character and location in the area of the national park, Lake Morskie Oko is not subject to large-scale anthropopressure. Therefore, it can serve as an indicator of the observed global climatic changes. The data presented in this paper confirm the current assumptions concerning climate warming and its effects on water ecosystems. The tendencies of the changes, maintained at the present level lead, and will lead to transformations of the current state of Lake Morskie Oko, manifested in processes related to water mixing, thermal-density stratification, or changes in the species composition of flora and fauna.

\section{REFERENCES}

Adrian, R., O'Reilly, C.M., Zagarese, H., Baines, S.B., Hessen, D.O., Keller, W., Livingstone, D.M., Sommaruga, R., Straile, D., Van Donk, E., Weyhenmeyer, G.A., Winder, M., 2009. Lakes as sentinels of climate change. Limnology and Oceanography, 54, 6, 2, 2283-2297.

Apsite, E., Elferts, D., Zubaničs, A., Latkovska, I., 2014. Longterm changes in hydrological regime of the lakes in Latvia. Hydrology Research, 45, 3, 308-321.

Benson, B.J., Magnuson, J.J., Jensen, O.P., Card, V.M., Hodgkins, G., Korhonen, J., Livingstone, D.M., Stewart, K.M., Weyhenmeyer, G.A., Granin, N.G., 2012. Extreme events, trends, and variability in Northern Hemisphere lake-ice phenology (1855-2005). Climatic Change, 112, 2, 299-323.

Bukowski, M., 2009. Dynamics of overgrowing of Tatra Mountains clearings. In: Długookresowe zmiany w przyrodzie i użytkowaniu TPN. Tatrzański Park Narodowy, Zakopane. (In Polish.)

Cengiz, T.M., 2011. Periodic structures of Great Lakes levels using wavelet analysis. Journal of Hydrology and Hydromechanics, 59, 1, 24-35.

Choiński, A., Ptak, M., Strzelczak, A., 2013. Areal variation in ice cover thickness on lake Morskie Oko (Tatra Mountains). Carpathian Journal of Earth and Environmental Sciences, 8, $3,97-102$.

Choiński, A., Ptak, M., Skowron, R., Strzelczak, A., 2015a. Changes in ice phenology on Polish lakes from 1961-2010 related to location and morphometry. Limnologica, 53, 42-49.

Choiński, A., Ptak, M., Strzelczak, A., 2015 b. Changeability of accumulated heat content in alpine-type lakes. Polish Journal of Environmental Studies, 24, 6, 2363-2369.

Coats, R., Perez- Losada, J., Schladow, G., Richards, R., Goldman, C., 2006. The warming of Lake Tahoe. Climatic Change, 76, 1-2, 121-148.

Dočkalová, K., Holubcová, J., Bacardit, M., Bartrons, M., Camarero, L., Gallego, E., Grimalt, J.O., Hardekopf, D., Hořická, Z., Rosseland, B.O., Tátosová, J., Stuchlík, E., 2015. Brown and brook trout populations in the Tatra Mountain lakes (Slovakia, Poland) and contamination by longrange transported pollutants. Biologia, 70, 4, 516-529.

Dokulil, M.T., Teubner, K., Jagsch, A., Nickus, U., Adrian, R., Straile, D., Jankowski, T., Herzig, A., Padisak, J., 2010. The impact of climate change on lakes in Central Europe. In: George, D.G. (Ed.): The Impact of Climate Change on European Lakes. Aquatic Ecology Series 4. Springer, Dordrecht, The Netherlands, pp. 387-409.

Futter, M.N., 2003. Patterns and trends in southern Ontario Lake ice phenology. Environmental Monitoring and Assessment, 88, 431-444.

Gądek, B., 2014. Climatic sensitivity of the non-glaciated mountains cryosphere (Tatra Mts., Poland and Slovakia). Global and Planetary Change, 121, 1-8.

Gąsiorowski, M., Sienkiewicz, E., 2010. 20th century acidification and warming as recorded in two alpine lakes in the Tatra Mountains (South Poland, Europe). Science of the Total Environment, 408, 5, 1091-1101.

Gregor, V., Pacl, J., 2005. Hydrology of the Tatra Mountain lakes. Acta Hydrologica Slovaca, 6, 161-187. (In Slovak.)

Hamerlík, L., Bitušík, P., 2009. The distribution of littoral chironomids along an altitudinal gradient in High Tatra Mountain lakes: Could they be used as indicators of climate change? Annales de Limnologie, 45, 3, 145-156.

Hamerlík, L., Dobríková, D., Szarlowicz, K., Reczynski, W., Kubica, B., Šporka, F., Bitušík, P., 2016. Lake biota response to human impact and local climate during the last 200years: A multi-proxy study of a subalpine lake (Tatra Mountains, W Carpathians). Science of the Total Environment, 545-546, 320-328.

Hampton, S.E., Izmest'eva, L.R., Moore, M.V., Katz, S.L., Dennis, B., Silow, E.A., 2008. Sixty years of environmental change in the world's largest freshwater lake - Lake Baikal. Siberia, Global Change Biology, 14, 8, 1947-1958.

Hesse, T., Lampart-Kaluznicka, M., Kot, M., Popowic, D., Żurek, R., 2014. Stream trout (Salmno trutta morpha fario., 1758) in Morskie Oko. In: Choiński, A., Pociask-Karteczka, J. (Eds.): Morskie Oko - przyroda i człowiek. TPN, Zakopane. (In Polish.) 
Ivanković, A., Habul, E.V., Knezović, Z., 2011. Physicochemical characteristics of shallow, high mountains Lake Blidinje (in a karst area of Bosnia and Herzegovina) with emphasis on its trophic status. Oceanological and Hydrobiological Studies, 40, 3, 19-27.

Jańczak, J., Choiński, A., 1988. Water level fluctuations in selected lakes in Poland in the years 1956-1985. In: Churski, Z. (Ed.): Natural and Anthropogenic Transformations of Lakes and Wetlands in Poland. UMK, Torun. (In Polish.)

Jeppesen, E., Meerhoff, M., Holmgren, K., GonzálezBergonzoni, I., Teixeira-de Mello, F., Declerck, S.A.J., DeMeester, L., Søndergaard, M., Lauridsen, T.L., Bjerring, R., Conde-Porcuna, J.M., Mazzeo, N., Iglesias, C., Reizenstein, M., Malmquist, H.J., Liu, Z., Balayla, D., Lazzaro, X., 2010. Impacts of climate warming on lake fish community structure and potential effects on ecosystem function. Hydrobiologia, 646, 73-90.

Jeppesen, E., Mehner, T., Winfield, I.J., Kangur, K., Sarvala, J., Gerdeaux, D., Rask, M., Malmquist, H.J., Holmgren, K., Volta, P., et al. 2012. Impacts of climate warming on the long-term dynamics of key fish species in 24 European lakes. Hydrobiologia, 694, 1-39.

Kabała, C., Bojko, O., 2014. Trends in trace element concentrations in holocene bottom sediments of a lake Wielki Staw in the Karkonosze Mountains. Polish Journal of Environmental Studies, 23, 2, 357-362.

Kawecka, B., Galas, J., 2003. Diversity of epilithic diatoms in high mountain lakes under the stress of acidification (Tatra Mts, Poland). Annales de Limnologie, 39, 239-253.

Korhonen, J., 2006. Long-term changes in lake ice cover in Finland. Nordic Hydrology, 4-5, 347-363.

Lenarczyk, J., Tsarenko, P., 2013. Some rare and interesting green algae (Chlorophyta) from subalpine Tatra lakes (High Tatra Mountains, Poland). Oceanological and Hydrobiological Studies, 43, 3, 225-232.

Livingstone, D.M., 2003. Impact of secular climate change on the thermal structure of a large temperate Central European lake. Climatic Change, 57, 1-2, 205-225.

Magee, M.R., Wu, C.H., Robertson, D.M., Lathrop, R.C., Hamilton, D.P., 2016. Trends and abrupt changes in 104 years of ice cover and water temperature in a dimictic lake in response to air temperature, wind speed, and water clarity drivers. Hydrology and Earth System Sciences, 20, 5, 16811702.

Marszelewski, W., Skowron, R., 2006. Ice cover as an indicator of winter air temperature changes: Case study of the Polish Lowland lakes. Hydrological Sciences Journal, 51, 2, 336349.

Moiseenko, T.I., Dauvalter, V.A., Kagan, L.Ya, 1997. Mountain lakes as indicators of air pollution. Water Resources, 24, $5,556-564$.

Niedźwiedź, T., Twardosz, R., 2004. Long-term variability of precipitation at selected stations in Central Europe. Global Change, 11, 73-100.

Novikmec, M., Svitok, M., Kočický, D., Šporka, F., Bitušík P., 2013. Surface water temperature and ice cover of Tatra Mountains lakes depend on altitude, topographic shading, and bathymetry. Arctic, Antarctic, and Alpine Research, 45, $1,77-87$.

Ohlendorf, C., Bigler, C., Goudsmit, G.H., Lemcke, G., Livingstone, D.M., Lotter, A.F., Müller, B., Sturm, M., 2000. Causes and effects of long periods of ice cover on a remote high Alpine lake. Journal of Limnology, 59, Suppl. 1, 65-80.
Pawłowski, B., 2015. Determinants of change in the duration of ice phenomena on the Vistula River in Torun. Journal of Hydrology and Hydromechanics, 63, 2, 145-153.

Pociask-Karteczka, J., Choiński, A., 2012. Recent trends in ice cover duration for Lake Morskie Oko (Tatra Mountains, East-Central Europe). Hydrology Research, 43, 4, 500-506.

Pociask-Karteczka, J., Choiński, A., Nieckarz, Z., 2014. Dynamics of water stages. In: Choiński, A., PociaskKarteczka, J. (Eds.): Morskie Oko - przyroda i człowiek. TPN, Zakopane. (In Polish.)

Procházková, L., Houk, V., Nedbalová, L., 2012. Discostella tatrica sp. nov. (Bacillariophyceae) - a small centric diatom from the Tatra Mountain lakes (Slovakia/Poland). Fottea, 12, $1,1-12$.

Rempfer, J., Livingstone, D.M., Blodau, C., Forster, R., Niederhauser, P., Kipfer, R., 2010. The effect of the exceptionally mild European winter of 2006-2007 on temperature and oxygen profiles in lakes in Switzerland: A foretaste of the future? Limnology and Oceanography, 55, 5, 2170 2180.

Rzychoń, D., Worsztynowicz, A., 2008. What affects the nitrogen retention in Tatra Mountains lakes' catchments in Poland? Hydrology and Earth System Sciences, 12, 2, 415424.

Salmi, T., Määttä, A., Anttila, P., Ruoho- Airola, T., Ammell, T., 2002. Detecting Trends of Annual Values of Atmospheric Pollutants by the Mann-Kendall Test and Sen's Slope Estimates - the Excel Template Application MAKESENS. Publications on Air Quality No. 31. Finnish Meteorological Institute, Helsinki, $35 \mathrm{p}$.

Šporka, F., Livingstone, D.M., Stuchlík, E., Turek, J., Galas J., 2006. Water temperatures and ice cover in lakes of the Tatra Mountains. Biologia, Bratislava, 61, Suppl.18, S77-S90.

Strong, C., Maberly, S.C., 2011. The influence of atmospheric wave dynamics on interannual variation in the surface temperature of lakes in the English Lake District. Global Change Biology, 17, 6, 2013-2022.

Thompson, R., Kamenik, C., Schmidt, R., 2005. Ultra-sensitive Alpine lakes and climate change. Journal of Limnology, 64, 2, 139-152.

Tiberti, R., Rogora, M., Tartari, G., Callieri, C., 2014. Ecological impact of transhumance on the trophic state of alpine lakes in Gran Paradiso National Park. Knowledge and Management of Aquatic Ecosystems, 415, Art. No. 05, $1-17$.

Van Drooge, B.L., López, J., Fernández, P., Grimalt, J.O., Stuchlík, E., 2011. Polycyclic aromatic hydrocarbons in lake sediments from the High Tatras. Environmental Pollution, 159, 5, 1234-1240.

Wit-Jóźwik, K., 1974. Hydrography of High Tatra Mountains. Explanations to the hydrographic map "High Tatra Mountains" 1:50000. Dokumentacja Geograficzna, z. 5, IG PAN, Warszawa. (In Polish.)

Wrzesiński, D., Choiński, A., Ptak, M., 2015. Effect of the North Atlantic Oscillation on the thermal characteristics of lakes in Poland. Acta Geophysica, 63, 3, 863-883.

Ziemońska, Z., 1974. Comment on the hydrography of the Polish Tata Mountains. Przegląd Geograficzny, 1, 63-74. (In Polish.)

Received 1 April 2016 Accepted 29 June 2016 